\title{
The Empirical Analysis of the Core Competencies of the Company's Resource Management Risk. Preliminary Study
}

\author{
Grzegorz Drozdowski ${ }^{1, * \mathbb{C}}$, Joanna Rogozińska-Mitrut ${ }^{2}$ and Jacek Stasiak ${ }^{3}$ \\ 1 Department of Economics and Finance, Faculty of Law and Social Sciences, Jan Kochanowski University \\ in Kielce, 25-369 Kielce, Poland \\ 2 Economic Department, Jacob of Paradise University in Gorzów Wielkopolski, 66-400 Gorzów Wielkopolski, \\ Poland; joanna_rogozinska@wp.pl \\ 3 Non-Public Health Care Center Interschool Department of Rehabilitation and Correction—Scientific Research \\ Center, 95-070 Aleksandrów Łódzki, Poland; jacek_stasiak@interia.pl \\ * Correspondence: drozdowskigp@gmail.com
}

check for

updates

Citation: Drozdowski, Grzegorz, Joanna Rogozińska-Mitrut, and Jacek Stasiak. 2021. The Empirical Analysis of the Core Competencies of the Company's Resource Management Risk. Preliminary Study. Risks 9: 107. https://doi.org/10.3390/

risks 9060107

Academic Editor:

Zbysław Dobrowolski

Received: 6 February 2021

Accepted: 26 May 2021

Published: 3 June 2021

Publisher's Note: MDPI stays neutral with regard to jurisdictional claims in published maps and institutional affiliations.

Copyright: (c) 2021 by the authors. Licensee MDPI, Basel, Switzerland. This article is an open access article distributed under the terms and conditions of the Creative Commons Attribution (CC BY) license (https:/ / creativecommons.org/licenses/by/ $4.0 /)$.

\begin{abstract}
The occurrence of the COVID-19 pandemic revealed many weaknesses in the functioning of businesses. It turns out that managers are not prepared to manage the enterprise's resources in a high-risk environment. Considering risk managers' issues requires reaching for theoretical and practical knowledge about competencies shaped in unpredictable conditions. This study attempts to determine the importance of the company's resource management risk among the managerial staff. For the research carried out in 2019-2020, a questionnaire, interview, and literature studies were used. The questionnaire was addressed to 282 managers from western Poland. Particular attention was paid to establishing the crucial components of the company's resource management competence. Moreover, the regular self-assessment of risk competence made it possible to present preferences in managing strategic resources, depending on the type of position held. The competence of human resources management risk was also examined according to biographical variables (i.e., age, sex, seniority, and total seniority).
\end{abstract}

Keywords: risk competencies; risk management; company resources; manager; risk

\section{Introduction}

Companies are currently undergoing dynamic and complex changes which contribute to complex management problems. The COVID-19 pandemic crisis compounds these changes. The creation of quality company management decreases, directly and indirectly, due to increased operational risk. Managers are required to have competence to effectively manage an enterprise's resources, determined by the impact of risk and, increasingly, uncertainty.

Some disruptive factors characterize the resulting pandemic crisis and its impact on business management. In this type of situation, two groups of crisis factors overlap. First of all, managers are subject to constant adjustments as part of the internal competence system's ongoing changes. Secondly, as part of the external crisis impact system, managers must consider dynamic adaptation behavior within their competence potential. Thirdly, the competence profiles of managers are subject to change. Transformations in attitudes, behaviors, skills, personality traits, values, attitudes, and other competence attributes are noticeable. It can be seen that the increasing level of risk in managers' work contributes, on one hand, to the need for faster implementation of crisis adjustment mechanisms. On the other hand, it causes many phenomena that reduce the possibility of effective use of available resources. Aside from that, the high instability of the company's internal and external environments' basic parameters makes it difficult for the managerial staff to take advantage of its resource management risk competence.

When looking at the issue of competencies developed in high-risk conditions, it can be concluded that managers are increasingly operating in conditions of uncertainty 
(Dobrowolski 2020b; Drozdowski 2021). To a large extent, managers are not ready to respond skillfully and proactively to unforeseen situations. Companies seeking a more competitive position in a turbulent environment need a strong foundation based on competent managers. Apart from employees' knowledge and skills, managers' competencies determine any organization's success. There are many studies on this issue (e.g., Cockerill et al. 1995; Noordegraaf 2000; Abraham et al. 2001; Smith and Morse 2005; Levenson et al. 2006; Johannisson and Huse 2010; Agyapong et al. 2016; Winterton 2019; Vainieri et al. 2019). However, it seems premature to say that everything has already been discovered in the competencies of managers. This study aims to identify the primary areas of competencies that risk enterprise resource management, which characterized the surveyed managers. The research then seeks to determine how the respondents' biographical variables affect enterprise resource management's risk assessment competency.

The article is structured as follows. First, we discuss the literature review on enterprise resource management's risk competencies. Then, we present the methodologies and results of the research carried out. Finally, we formulate a conclusion and indicate possibilities for further studies.

\section{Literature Review}

In each company, the scale of risk remains at a different level. Many researchers point to the emphasis on risk assessment in business management (Simunic and Stein 1990; Friedlob and Schleifer 1999; Reamer 2000; Barney 2002; Christensen et al. 2013; Knight 2013; Amir et al. 2014; Gramling and Schneider 2018; Dziekański and Prus 2020; González-Díaz et al. 2021), showing that in a highly volatile environment, the ability to assess risk is a manager's competence when it concerns objective phenomena correlated with the adverse condition's subjective uncertainty. From the manager's competence in managing the company's resources, it can be concluded that the risk is related to the risk of failure to implement the actions assumed when making a specific decision (Renn 2020; Wysokińska-Senkus and Górna 2021). The danger of not carrying out certain activities is due to two factors. The first factor includes the lack of appropriate competence in managing the company's resources. The second factor is the loss of ability or the ability of the company's management to influence the situation's shaping of the company's resources. That aside, it should be noted that competency is a multidimensional concept, which causes difficulties in its definition and classification. An attempt to diagnose competence proved that we deal with a kind of "black box" (Dubois 1998; Straka 2004). The tendency to consider competency as an issue with an unclear structure and endpoints is widely identified in the literature (Spencer and Spencer 1993; Hockemeyer et al. 2003; Stevens 2013; Müller-Frommeyer et al. 2017).

However, regardless of the level at which managers assess risk, they should also be sensitive to uncertainties in considering different decision-making options. A competent manager should consider this option, which is close to the most optimal solution for the change. In the current instability in the environment, the shaping of managers risk competencies occurs in the sphere of specificity and indefiniteness. The scope of each sphere depends on factors that affect the functioning of the management staff. The individual components of the environment have a significant impact on enterprise resource management risk's competence. Their properties allow defining of the risks of managers' decisions and actions (Feldmann-Jensen et al. 2019; Klinke and Renn 2019; Krause et al. 2020; Aven and Bouder 2020).

Particular attention should be paid to the sphere of indefiniteness, whose field of influence expands with the time horizon extension and uncertainty caused by the COVID19 pandemic. Klinke (2020) describes tension as the need for a manager to decide on a specific activity without complete information about the reality in which it will take place. From a statistical perspective, uncertainty refers to a situation with an unknown probability distribution of future operating conditions, so it is not measurable. Thus, 
tension is beyond the manager's control, and the decision is already made (Cook 1988; Alaszewski and Coxon 2008; Samson et al. 2009; Renn et al. 2011; Buhaichuk et al. 2021).

Certain types of risk behavior characterize managers. The assessment of the risk level often depends on the subjective evaluation of the person making the decision. When it comes to the risks involved in managing a company's strategic resources, which depend on human uncertainty and aversion to risk, different people make their decisions based on their attitudes to risk. This relationship is usually subjective. Three types of risk behavior characterize managers:

(a) The manager is willing to take a high risk in managing the company's resources, counting on more-than-average profit;

(b) Risk neutrality, where the manager makes decisions based on the value of the expected rate of return;

(c) Risk aversion, where the manager prefers to minimize uncertainty (Fehr and Rangel 2011).

The desire to shape the expected competencies is evidence of the growing awareness that competent people are the primary source of enterprise value creation (Kohnová et al. 2020). Therefore, increasing emphasis is placed on examining the different competencies, especially those representing companies operating in central and eastern European countries (Berber and Lekovic 2018; Bercu and Lupu 2020).

The assumptions laid out above, under the basis of interest in competencies, show the need for empirical verification. This is reflected not only in the market for studying the company's development conditions but also in the often poorly understood subject of the causes of the emerging competence gap for the ability to diagnose the risk of managing the company's resources (Scholes and Endacott 2003; Kuk et al. 2007; Kralj 2018). Therefore, an important issue is continually monitoring the staff's attitudes to improve their competencies and systematically analyze their component structures (Martin and Rubin 1995; Taborsky and Oliveira 2012; Drozdowski 2017; Wu et al. 2020). The results of such research can be a tool for early warnings of the company's problems and serve as a basis for developing programs to introduce changes and shape future human capital development (Dobrowolski 2020a). The findings of this research can improve the functions of businesses, particularly in human capital management.

\section{Materials and Methods}

We thought that we should analyze the risk competencies of company resource managers in a situational context. The changes taking place in a company's environment are often random. Managers should consider the state of risk that accompanies their actions when predicting the outcomes of their decisions. Another situation occurs where the process of managing a company's unique resources takes place in conditions of uncertainty (Aven and Renn 2009). Regarding company resource management, precarious situations are those whose outcomes depend both on a person and events beyond their control, but the events cannot be predicted or measured (Aven and Bouder 2020). The readiness to be personally involved in the risk assessment process is vital to managers' competence as they manage the company's strategic resources.

Aside from that, the problem of risk being associated with forming the enterprise's resources should, to no small extent, also include managerial concepts. From the point of view of research currents, we can distinguish the following:

(a) The concept derived from the work of Knight (2013), in which the main emphasis is on the manager's ability to bear risks;

(b) The current related to the research conducted by Schumpeter (2003), which emphasizes the manager's entrepreneurial abilities;

(c) Fiedler's (1981) theory based on the manager's personality traits determined by situational conditions.

Each of the research concepts mentioned has had a significant impact on the development of management theory. At the same time, it is worth noting the convergence between 
the approach from the risk propensity side and the set of human personality traits that determine the manager's behavior in specific situations (Le Blanc et al. 2020).

The conducted research's main objective is to show managers' behavior using their resource management risk competence. On this basis, we attempted to answer the following question: What are the crucial areas of competence for enterprise resource management risks among managers operating in a highly volatile environment? To this end, it was necessary to empirically determine the dominant areas of competence for managing the company's strategic resources of the surveyed power. Another issue related to the research objective was determining resource management risk competence, depending on the existing control variables (e.g., age, sex, managerial seniority, total seniority, and position). The empirical context of the objective is a basis for assessing how managers perceive the need to shape their risk competencies under increasingly uncertain conditions.

In the adopted research model, six critical areas of business management risk were identified: organizational resource management risk (ORMR), marketing resource management risk (MRMR), technological resource management risk (TRMR), legal resource management risk (LRMR), financial resource management risk (FRMR), and human resource management risk (HRMR). The chances of managing the company's resources influence the management's decisions and actions (Mintzberg et al. 2009). The company's management's presented risk areas were specified based on the analysis of factors shaping their strategic environment (Prahalad and Hamel 1997; Cole 2006; Aven and Renn 2010). The central hypothesis is as follows: The managerial staff's competence in managing the company's resource risks has a different rank, determined by biographical features. The above assumptions provided the basis for formulating the following six specific hypotheses:

Hypothesis 1 (H1). The competencies of technological resource management risk are dominant among managers.

Hypothesis $\mathbf{2} \mathbf{( H 2 )}$. As the hierarchical position in the company increases, the risk competence of organizational resource management increases, while the importance of technological risk knowledge decreases.

Hypothesis 3 (H3). Women and men holding managerial positions have the same competencies in the six selected areas of enterprise resource management risk.

Hypothesis 4 (H4). There is no correlation between the age of the surveyed persons and the competencies of the enterprise resource management risk.

Hypothesis 5 (H5). The total length of service is related to the type of competencies held in particular areas of risk.

Hypothesis 6 (H6). Risk competence in organizational resource management characterizes managers with short managerial tenure.

The surveyed population consisted of 282 persons holding managerial positions at three levels in their enterprises' organizational structures. The highest level in the hierarchical structure included 42 people. The average management level included 152 people. The third group of people surveyed (the lowest level) consisted of 88 managers. The research used a questionnaire, interview, and literature studies. The study was conducted in 20192020. Two hundred eighty-two managers from western Poland participated in the study. The subject of the study was the managers' managing of the companies' strategic resources. On the other hand, the research object was the competence of the enterprise resource management risk shaped by the changes taking place in the enterprise environment. When testing, we verified the hypotheses with a percentage distribution. 
There was a negative attitude among the studies' subjects toward the research of the phenomenon under analysis. Therefore, in the test procedure, the following measures were taken:

(a) Several methods obtained data on the competence of the employees;

(b) Interviews with respondents supplemented the results of the questionnaire tests;

(c) Personal supervision of the conduct of the test procedure was ensured;

(d) The principle of voluntary participation in the research was respected.

\section{Results}

Based on the verification of theoretical assumptions, the empirical characteristics of the risk competencies were presented, depending on the surveyed managers' biographical elements. The analysis of the first hypothesis (H1) showed the following relationships. Among the six examined areas of enterprise resource management risk, it was found that the analyzed managers' competence was essentially determined by their knowledge of technology risk in the period under examination. Table 1 shows the percentage distribution of the six crucial dimensions of competence of business management risk managers. Statistical analysis confirmed the theoretical investigations contained in the first hypothesis (H1).

Table 1. Percentage distribution of the six core competence areas of corporate resource management risk.

\begin{tabular}{ccccccccc}
\hline \multirow{2}{*}{ Variable Tested } & \multicolumn{4}{c}{ Risk Management Competence } & \multicolumn{2}{c}{ Total } \\
\cline { 2 - 7 } & ORMP & MRMR & TRMR & LMRM & FRMR & HRMR & \\
\hline Assessment of competence & 32 & 6 & 36 & 4 & 14 & 8 & 100 \\
\hline
\end{tabular}

ORMR: organizational resource management risk, MRMR: marketing resource management risk, TRMR: technological resource management risk, LMRM: legal resource management risk, FRMR: financial resource management risk, and HRMR: human resource management risk.

The interpretation of the obtained research results stated that technological resource management risk (36\%) was dominant in the managers. The overwhelming percentage of the surveyed persons with knowledge of technological risk showed the management staff's image, characterized primarily by competence in knowledge resources and manufacturing technology. Specific competencies of technical resource management risk mean the essential knowledge of quality and production methods adapted to a company's competitive position in the economic sector. The other dimensions of risk competence are as follows:

- Competencies of organizational resource management risk (32\%);

- $\quad$ Competencies of financial resource management risk (14\%);

- $\quad$ Competencies of human resource management risk $(8 \%)$;

- $\quad$ Competencies of marketing resource management risk $(6 \%)$;

- Competencies of legal resource management risk (4\%).

The analysis of the research results showed a relationship $\left(h_{2}\right)$ between the type of position held and the managers' risk competencies in organizational resource management and technological resource management. The sample tested, depending on the executive structure level, identified different risk competence preferences (Table 2).

Table 2. Percentage distribution of the six core risk competence areas by management position.

\begin{tabular}{cccccccc}
\hline \multirow{2}{*}{ Management Position } & \multicolumn{4}{c}{ Risk Management Competence } & \multicolumn{2}{c}{ Total } \\
\cline { 2 - 6 } & ORMP & MRMR & TRMP & LRMR & FRMP & HRMR & 12 \\
Highest & 39 & 9 & 27 & 0 & 13 & 100 \\
Average & 29 & 11 & 36 & 7 & 11 & 6 & 100 \\
Lowest & 28 & 0 & 44 & 6 & 17 & 5 & 100 \\
Overall assessment & 32 & 6 & 36 & 4 & 14 & 8 & 100 \\
\hline
\end{tabular}

Abbreviations are as defined in Table 1. 
This is evidenced by a statistical analysis of the relationship between the competence to manage the company and the manager's position in the organizational structure. Among the top managers surveyed, 39\% considered managerial resource management risk competencies to be the most important. In this group of managers, corporate resource management risk competence means a high degree of risk regarding company culture and organizational structure, decision-making processes, interpersonal relations, and relations with stakeholders. Similar research results were obtained at the average $(29 \%)$ and the lowest $(28 \%)$ levels in enterprises' organizational structures. Studies have shown the opposite trend in the case of risk management of technological resources. Risk managers considered their technical competence to be most important at the lowest level (44\%). At the middle class of the company's structure, $36 \%$ of managers considered technological resource management risk the most important. At the highest level, the percentage distribution was $27 \%$.

The interpretation of the obtained research results states that the managerial position held conditioned the resource management risk competence. The study results will conclude that with executive level growth, the organizational resource management risk increase and the technological resource management risks reduced. Additionally, top-level management staff showed less risk competence in managing financial (13\%), human (12\%), and marketing $(9 \%)$ resources. Of the top executives surveyed, no one indicated competence in legal resource management risk. The risk competence that characterized the surveyed managers in law at such a level proved the low qualifications for risk calculation of traditional standards (perceived high degree of legal instability and lack of influence on lawmaking). Similar results were obtained at other management levels. The surveyed managerial staff did not have excellent competence in managing company resources, especially in law and marketing (promotion, market research, and pricing policy). Aside from that, the surveyed managers recognized the risk competence of financial resource management (liabilities, capital, and liquidity) and human resource management (employee competence) at a medium level.

The third hypothesis (H3) verification determined the relationship between sex and the competence of the company's resource management risk. The sex of the respondents determined the competence of enterprise resource management risk (Table 3). In women in managerial positions, understanding the risk of managing organizational resources was a dominant competence (34\%). The men surveyed assessed the competence of technological resource management risk at the highest level. The percentage of distribution was $42 \%$. The third hypothesis (H3) was confirmed.

Table 3. Percentage distribution of risk competence according to sex.

\begin{tabular}{|c|c|c|c|c|c|c|c|}
\hline \multirow{2}{*}{ Sex } & \multicolumn{6}{|c|}{ Risk Management Competence } & \multirow{2}{*}{ Total } \\
\hline & ORMP & MRMR & TRMP & LRMR & FRMP & HRMR & \\
\hline Women & 34 & 8 & 30 & 5 & 12 & 11 & 100 \\
\hline Men & 30 & 3 & 42 & 3 & 16 & 6 & 100 \\
\hline
\end{tabular}

Abbreviations are as defined in Table 1.

The research results' interpretation shows that the surveyed managers' risk competence differed according to sex. The relationships obtained are as follows. In women in managerial positions, the competence to manage organizational resource risk occurred at the highest level. A relatively necessary competence was also knowledge of technology risks. The opposite trend was observed among men. They valued the competence of technological resource management risk most strongly. In the next place, they placed the knowledge of organizational risk in the assessment of their competencies.

The analysis did not confirm the fourth hypothesis (H4) in that there was no link between age and the company's resource management risk. It was found that among those surveyed up to 50 years of age, knowledge of the dangers of organizational resource management was predominant. The percentage of distribution was $34 \%$. On the other 
hand, for managers over 50 , the competence of technological resource management risk reached $57 \%$ (Table 4 ).

Table 4. Percentage distribution of risk competencies according to the age of management staff.

\begin{tabular}{ccccccccc}
\hline \multirow{2}{*}{ The Age Range (Years) } & \multicolumn{6}{c}{ Risk Management Competence } & \multirow{2}{*}{ Total } \\
\cline { 2 - 7 } & ORMP & MRMR & TRMP & LRMR & FRMP & HRMR & \\
\hline Up to 50 & 34 & 10 & 15 & 6 & 24 & 11 & 100 \\
Over 50 & 30 & 2 & 57 & 1 & 4 & 6 & 100 \\
\hline
\end{tabular}

Abbreviations are as defined in Table 1.

The research results' interpretation does not explain the relationship between the surveyed persons' ages and their resource risk management, which characterize their competencies. The analysis showed that mainly junior managers identified themselves with the competence of trouble in managing organizational resources. Aside from that, it should be noted that managers over fifty years old indicated a predominant knowledge of the dangers of managing technological resources.

The analysis showed that the entire managerial staff's total seniority was related to their competence in managing company resources (Table 5). The research showed that organizational resource management risk competencies often characterized managers with 15 years of experience. The percentage of distribution was $35 \%$. On the other hand, for managers with more than 15 years of seniority, the dominant competence of risk was technology knowledge. The percentage of distribution was 37\%. The fifth hypothesis (H5) was confirmed based on the results obtained.

Table 5. Percentage distribution of risk competencies according to the total seniority of managers.

\begin{tabular}{|c|c|c|c|c|c|c|c|}
\hline \multirow{2}{*}{ Total Seniority (Years) } & \multicolumn{6}{|c|}{ Risk Management Competence } & \multirow{2}{*}{ Total } \\
\hline & ORMP & MRMR & TRMP & LRMR & FRMP & HRMR & \\
\hline Up to 15 & 35 & 5 & 34 & 5 & 16 & 5 & 100 \\
\hline Over 15 & 29 & 7 & 37 & 3 & 12 & 12 & 100 \\
\hline
\end{tabular}

Abbreviations are as defined in Table 1.

The interpretation of the research results showed that the state of risk competence, considered in terms of enterprise resource management, was also verified by the total seniority. It was found that the long seniority of managers in the surveyed companies showed an analytical tendency; due to this, the competence of technological resource management risk was dominant (37\%). On the other hand, for managers with shorter total seniority, the competence of organizational resource management risk was rated highest (35\%).

Analysis of the sixth hypothesis (H6) showed the relationship between short managerial experience and risk competence in organizational knowledge (Table 6). The survey results indicated a trend characterizing corporate resource management risk in managers with up to 10 years (the respondents' percentage distribution was $32 \%$ ). The sixth hypothesis (H6) was confirmed.

Table 6. Percentage distribution of risk competencies according to managers' seniority.

\begin{tabular}{cccccccc}
\hline \multirow{2}{*}{$\begin{array}{c}\text { Management } \\
\text { Traineeship (Years) }\end{array}$} & \multicolumn{6}{c}{ Risk Management Competence } & \multirow{2}{*}{ Total } \\
\cline { 2 - 7 } & ORMP & MRMR & TRMP & LRMR & FRMP & HRMR & \\
\hline Up to 10 & 32 & 9 & 27 & 4 & 20 & 8 & 100 \\
Over 10 & 31 & 3 & 45 & 4 & 8 & 9 & 100 \\
\hline
\end{tabular}

Abbreviations are as defined in Table 1. 
The research results' interpretation allowed us to state a link between the managers of the surveyed companies' dominant risk management competencies of organizational resources and short managerial experience. On the other hand, risk competencies identified at the technical knowledge level were predominant in managers with more vast administrative expertise ( $45 \%)$.

\section{Conclusions}

Based on the collected empirical material, we formulated the following practical conclusions:

1. The analysis of the research results showed a gradation of separate dimensions of resource management risk competence. The dominant ones were the competencies of technological resource management risk. The management risk competencies were the following: organizational resources, financial resources, human resources, marketing resources, and legal resources (Figure 1);

2. From the adopted research concept, managers' biographical characteristics were an essential parameter for characterizing the differences in the six identified areas of competence of an enterprise's resource management risk;

3. The analysis of interdependencies between the type of risk competence and biographical variables of the management team allowed for the verification of six detailed hypotheses. The presented calculations show that the positions occupied by the persons surveyed in the companies' structures determined risk competence. As the management levels increased, organizational resource management risk increased and technological resource management risk decreased;

4. Moreover, based on the performed analyses, the following was noted:

(a) Sex was the feature that influenced the type of risk competencies held by the managerial staff. It was found that the competence of the company's resource management risk in women and men in executive positions was different;

(b) The ages of the surveyed persons significantly determined the risk competencies of the managers;

(c) There were differences between the length of seniority in general and the possessed competencies of risk;

(d) Short seniority for the managers influenced the competencies of organizational resource management risk.

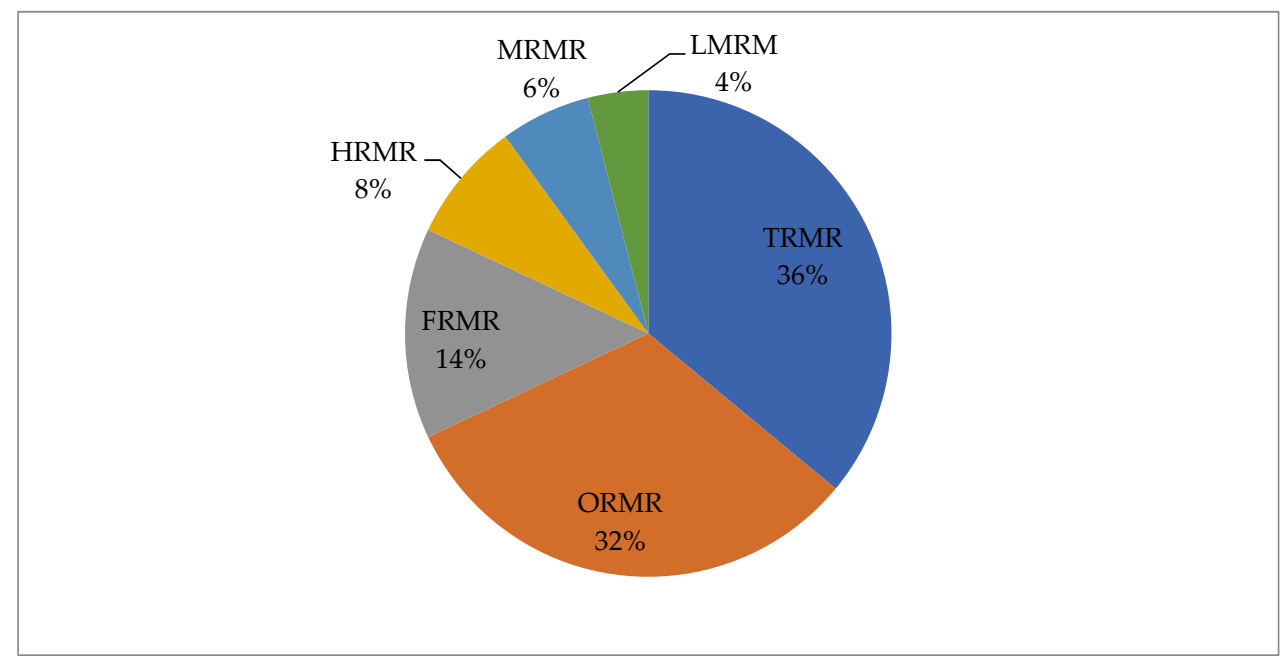

Figure 1. Risk competencies of enterprise resource management. Abbreviations are as defined in Table 1.

The collected empirical material and literature studies made it possible to make a scientific diagnosis in risk management competence: 
1. We justified the advisability of applying a scientific approach to research on company resource risk management. This allows for deepening the characteristics of managers' work. Competence is a multidimensional concept and requires an integrated approach that helps build a managerial competence model that reflects today's environment's objective complexity and dynamics;

2. We have shown scientific and practical evidence of the link between the business environment and managers' risk competencies. We pointed out that it is necessary to analyze managerial risk competence dimensions in highly unstable conditions continuously;

3. From the empirical point of view, we classified the individual areas of competence for managing a company's resources. The research carried out allowed us to order the importance (levels) of the individual components of risk competence (Figure 2);

4. We have shown scientific and practical evidence of the relationship between crucial risk competencies and characterizing managers' biographical variables.

\begin{tabular}{|c|c|}
\hline level 6 & •technological resources management risk \\
\hline level 5 & • organizational resources management risk \\
\hline level 4 & - financial resources management risk \\
\hline level 3 & - human resources management risk \\
\hline level 2 & - marketing resources management risk \\
\hline level 1 & •legal resources management risk \\
\hline
\end{tabular}

Figure 2. Risk levels of company resource management.

The development of a competence structure for the enterprise resource management risk described in the article is a starting point for further research. The presented study opens up possibilities of application verification of the created model for its further development. Research should be conducted in two directions. First of all, the research may shape human capital according to its resource management's identified competence areas. Secondly, the research should include practical recommendations to formulate and implement managers' risk management strategies. To this end, given managerial competence in creating company value, management practitioners and researchers should develop research for building risk management models. Risk competence in a highly volatile environment is the strategic capital of employees. Enterprises that bring together valuable people should encourage the creation of new competence models. Managers' competence models should consider people's skills when assessing the risk of managing the company's resources.

This study supported Smith and Morse's (2005) arguments that managerial competencies are multidimensional constructs. This multidimensionality in the conducted research refers to the risk competency of enterprise resource management. The study confirmed the findings of Andrews (1997) that the risk of managing a firm's resources should be considered in the area of managerial competence, as it is an essential component of the management process. This study shows that the company's resource management's risk assessment was material for the surveyed managers. We established six levels of risk for enterprise resource management.

The research confirmed (Dulewicz and Higgs 2005) findings regarding biographical variables' influence on managerial competence. The surveyed managers pointed to the risk competencies of managing technological and organizational resources as the ones possessed by most of them. These competencies can be grouped into the firm's resource management risk categories defined in the study by Gamble et al. (2013). 
Managers now operate in an uncertain environment, even more so than before the COVID-19 pandemic (Beseny”̋ and Kármán 2020). The current changing conditions of the pandemic environment have redefined the requirements for different risk competencies. The study was conducted before the onset of the COVID-19 pandemic. Therefore, it can be surmised that the contents of managers' competencies under the conditions of increased pandemic-induced uncertainty will continue to be strongly correlated with management's vision, which requires managers to be more competent in risk assessment. Continuous improvement of risk competence in the analysis of individual company resources by managers seems to be an effective strategy to increase management professionalism. The control variables suggest that individual biographical parameters have an impact on the possessed assessment of risk competence. The ability to diagnose the resource management risk competencies held is an added value for managers to reach a higher management level. Further research should aim to determine the direction in which managers should develop their competencies in enterprise resource management risk.

We suppose that this current résumé has already convinced the reader of the importance of risk competence in managing company resources. Its significance may be much greater than was shown in this paper. The unpredictability of the modern environment may determine a manager's predisposition to risk assessment in resource management. This is all the more applicable as probabilistic situations turn into precarious conditions due to the pandemic crisis. Therefore, the claim of limited rationality of the person making the decision seems convincing. The pandemic crisis's impact on developing crucial risk competencies provides a basis for further research among managers. We will see the full significance of these influences when we ask how the various risk competence dimensions affect company management's effectiveness. There is no doubt that as we increase our knowledge of the competence of resource management risks, we will better understand the extent to which we use the competence of managers in a highly volatile environment.

The authors assumed that the preliminary research showed the managerial competence in risk assessment of enterprise resource management in a small Polish manager group. Thus, the authors need to show modesty toward the generalizability of the findings and encourage future researchers to test whether these research findings hold in various firms and countries, especially when the results presented are compared with studies carried out after the pandemic has ended.

Author Contributions: Conceptualization, G.D., J.R.-M., and J.S.; methodology, G.D.; software, G.D., J.R.-M., and J.S.; validation, G.D.; formal analysis, G.D. and J.R.-M.; investigation, G.D.; resources, G.D., J.R.-M., and J.S.; data curation, G.D., J.R.-M., and J.S.; writing-original draft preparation, G.D., J.R.-M., and J.S.; writing—review and editing, G.D.; visualization, G.D. and J.S.; supervision, G.D., J.R.-M., and J.S.; project administration, G.D. All authors have read and agreed to the published version of the manuscript.

Funding: This research received no external funding.

Institutional Review Board Statement: Not applicable.

Informed Consent Statement: Not applicable.

Data Availability Statement: Not applicable.

Conflicts of Interest: The authors declare no conflict of interest.

\section{References}

Abraham, Steven. E., Lanny A. Karns, Karns Shaw, and Manuel A. Mena. 2001. Managerial competencies and the managerial performance appraisal process. Journal of Management Development 20: 842-52. [CrossRef]

Agyapong, Ahmed, Florence Ellis, and Daniel Domeher. 2016. Competitive strategy and performance of family businesses: Moderating effect of managerial and innovative capabilities. Journal of Small Business E Entrepreneurship 28: 449-77. [CrossRef]

Alaszewski, Andy, and Kirstie Coxon. 2008. The everyday experience of living with risk and uncertainty. Journal Health, Risk E Society 10: 413-20. [CrossRef] 
Amir, Eli, Juha Kallunki, and Henrik Nilsson. 2014. The association between individual audit partners' risk preferences and the composition of their client portfolios. Review of Accounting Studies 19: 103-33. [CrossRef]

Andrews, Kenneth. 1997. The Concept of Strategy. Homewood. In Resources, Firms, and Strategies: A Reader in the Resource-based Perspective. Edited by Nicolai J. Foss. New York: Oxford University Press.

Aven, Terje, and Frederic Bouder. 2020. The COVID-19 pandemic: How can risk science help? Journal of Risk Research 23: 849-54. [CrossRef]

Aven, Terje, and Ortwin Renn. 2010. Risk Management. In Risk Management and Governance. Risk, Governance and Society. Berlin/Heidelberg: Springer. [CrossRef]

Aven, Terje, and Ortwin Renn. 2009. On risk defined as an event where the outcome is uncertain. Journal of Risk Research 12: 1-11. [CrossRef]

Barney, Jay B. 2002. Gaining and Sustaining Competitive Advantage. Upper Saddle River: Prentice-Hall.

Berber, Nemania, and Bojan Lekovic. 2018. The impact of HR development on innovative performances in central and eastern European countries. Employee Relations 40: 762-86. [CrossRef]

Bercu, Anna-Maria, and Dan Lupu. 2020. Entrepreneurial Competencies as Strategic Tools: A Comparative Study for Eastern European Countries. Developing Entrepreneurial Competencies for Start-Ups and Small Business. [CrossRef]

Besenyő, Janos, and Marianna Kármán. 2020. Effects of COVID-19 pandemy on African health, political and economic strategy. Insights into Regional Development 2: 630-44. [CrossRef]

Buhaichuk, Kostiantyn, Nataliia Varenia, Vitalii Khodanovych, Maryna Kriepakova, and Valentyn Seredynskyi. 2021. Mechanism of formation of innovation security and activation of innovation activity of corporations. Entrepreneurship and Sustainability Issues 8: 402-19. [CrossRef]

Christensen, Brant E., Steven M. Glover, and David A. Wood. 2013. Extreme estimation uncertainty in fair value estimates Implications for audit assurance, Auditing. A Journal of Practice $\mathcal{E}$ Theory 31: 127-46. [CrossRef]

Cockerill, Tony, John Hunt, and Harry Schroder. 1995. Managerial Competencies: Fact or Fiction? Business Strategy Review 6: 1-12. [CrossRef]

Cole, Gerald A. 2006. Strategic Management: Theory and Practice, 2nd ed. London: Thomson Learning.

Cook, Roger M. 1988. Uncertainty in risk assessment: A probabilist's manifesto. Reliability Engineering E System Safety 23: 277-83. [CrossRef]

Dobrowolski, Zbysław. 2020a. After COVID-19: Reorientation of crisis management in crisis. Entrepreneurship and Sustainability Issues 8: 799-810. [CrossRef]

Dobrowolski, Zbysław. 2020b. The supreme audit institutions readiness to uncertainty. Entrepreneurship and Sustainability Issues 8: 513-25. [CrossRef]

Drozdowski, Grzegorz. 2017. Emotional components of competence among executives: An empirical study. Economic Annals-XXI 162: 89-92. [CrossRef]

Drozdowski, Grzegorz. 2021. Economic Calculus Qua an Instrument to Support Sustainable Development under Increasing Risk. Journal of Risk and Financial Management 14: 15. [CrossRef]

Dubois, David. 1998. Preface, The Competency Casebook: Twelve Studies in Competency-Based Performance Improvement. Amherst: HRD Press.

Dulewicz, Victor, and Malcolm Higgs. 2005. Assessing leadership dimensions, styles and organizational context. Journal of Managerial Psychology 20: 105-23. [CrossRef]

Dziekański, Paweł, and Piotr Prus. 2020. Financial Diversity and the Development Process: Case study of Rural Communes of Eastern Poland in 2009-2018. Sustainability 12: 6446. [CrossRef]

Fehr, Ernest, and Antonio Rangel. 2011. Neuroeconomic foundations of economic. choice recent advances, Journal of Economic Perspectives 25: 3-30. [CrossRef]

Feldmann-Jensen, Shirley, Steven J. Jensen, Sandy M. Smith, and Gregory Vigneaux. 2019. The next-generation core competencies for emergency management. Journal of Emergency Management 17: 17-25. [CrossRef]

Fiedler, Fred. 1981. Leadership Effectiveness. American Behavioral Scientist 24: 619-32. [CrossRef]

Friedlob, George T., and Lydia Schleifer. 1999. Fuzzy logic: Application for audit risk and uncertainty. Managerial Auditing Journal 14: 127-37. [CrossRef]

Gamble, John, Arthur Thompson, and Margaret Peteraf. 2013. Essentials of Strategic Management: The Quest for Competitive Advantage. New York: McGraw-Hill/Irwin.

González-Díaz, Romel R., Angel E. Acevedo-Duque, Santos L. G. Gómez, and Elena Cachicatari Vargas. 2021. Business counterintelligence as a protection strategy for SMEs. Entrepreneurship and Sustainability Issues 8: 340-52. [CrossRef]

Gramling, Audrey, and Arnold Schneider. 2018. Effects of reporting relationship and type of internal control deficiency on internal auditors' internal control evaluations. Managerial Auditing Journal 33: 318-35. [CrossRef]

Hockemeyer, Cord, Owen Conlan, Vincent Wade, and Dietrih Albert. 2003. Applying competence prerequisite structures for elearning and skill management. Journal of Universal Computer Science 9: 1428-36.

Johannisson, Bengt, and Morten Huse. 2010. Recruiting outside board members in the small family business: An ideological challenge. Entrepreneurship \& Regional Development 12: 353-78. [CrossRef]

Klinke, Andreas. 2020. Public understanding of risk and risk governance. Journal of Risk Research 24: 2-13. [CrossRef] 
Klinke, Andreas, and Ortwin Renn. 2019. The Coming of Age of Risk Governance. Risk Analysis, An International Journal 41: $544-57$. [CrossRef]

Knight, Frank H. 2013. The Economic Organization. London: Transaction Publishers.

Kohnová, Lucia, Jan Papula, Zuzana Papulová, Katarina Stachová, and Zdenko Stacho. 2020. Job mismatch: The phenomenon of overskilled employees as a result of poor managerial competences. Entrepreneurship and Sustainability Issues 8: 83-102. [CrossRef]

Kralj, Mariela. 2018. Competency Gap: Managers' Expectations and Students' Perceptions of the Importance of Soft Skills. Ph.D. dissertation, Rochester Institute of Technology, Dubrovink, Croatia. Available online: https://zir.nsk.hr/islandora/object/acmt\% 3A36 (accessed on 6 October 2020).

Krause, Nicole M., Isabelle Freiling, Becca Beets, and Dominique Brossard. 2020. Fact-checking as risk communication: The multilayered risk of misinformation in times of COVID-19. Journal of Risk Research 23: 1052-59. [CrossRef]

Kuk, Linda, Braian Cobb, and Cynthia Forrest. 2007. Perceptions of competencies of entry-level practitioners in student affairs. Journal of Student Affairs Research and Practice 44: 664-91. [CrossRef]

Le Blanc, Pascale, Vicente González-Romá, and Haijiang Wang. 2020. Charismatic Leadership and Work Team Innovative Behavior: The Role of Team Task Interdependence and Team Potency. Journal of Bussiness and Psychology 36: 333-46. [CrossRef]

Levenson, Alec R., Wim A. Van der Stede, and Susan G. Cohen. 2006. Measuring the Relationship Between Managerial Competencies and Performance. Journal o Management 32: 360-80. [CrossRef]

Martin, Matthew M., and Rebecca B. Rubin. 1995. A new measure of cognitive flexibility. Psychological Reports 76: 623-26. [CrossRef]

Mintzberg, Henry, Bruce Ahlstrand, and Joseph Lampel. 2009. Strategy Safari. Your Complete Guide Through the Wilds of Strategic Management. Harlow: Prentice-Hall.

Müller-Frommeyer, Lena C., Stephanie C. Aymans, Carina Bargmann, Simone Kauffeld, and Cristoph Herrmann. 2017. Introducing Competency Models as a Tool for Holistic Competency Development in Learning Factories: Challenges, Example and Future Application. Procedia Manufacturing 9: 307-14. [CrossRef]

Noordegraaf, Mirko. 2000. Professional sense-makers: Managerial competencies amidst ambiguity. International Journal of Public Sector Management 13: 319-32. [CrossRef]

Prahalad, Coimbatore K., and Gary Hamel. 1997. The Core Competence of the Corporation. In Strategische Unternehmungsplanung/Strategische Unternehmungsführung. Edited by Dietger Hahn and Bernhard Taylor. Heidelberg: Physica. [CrossRef]

Reamer, Frederic G. 2000. The Social Work Ethics Audit: A Risk-Management Strategy. Social Work 45: 355-66. [CrossRef]

Renn, Ortwin. 2020. New challenges for risk analysis: Systemic risks. Journal of Risk Research 24: 127-33. [CrossRef]

Renn, Ortwin, Andreas Klinke, and Marjolein van Asselt. 2011. Coping with Complexity, Uncertainty and Ambiguity in Risk Governance: A Synthesis. AMBIO 40: 231-46. [CrossRef]

Samson, Sundeep, James A. Reneke, and Margaret M. Wiecek. 2009. A review of different perspectives on uncertainty and risk and an alternative modelling paradigm. Reliability Engineering \& System Safety 94: 558-67. [CrossRef]

Scholes, Julie, and Ruth Endacott. 2003. The practice competency gap: Challenges that impede the introduction of national core competencies. Nursing in Critical Care 8: 68-77. [CrossRef] [PubMed]

Schumpeter, Joseph. 2003. The Theory of Economic Development. In Joseph Alois Schumpeter. The European Heritage in Economics and the Social Sciences. Edited by J. Backhaus. Boston: Springer. [CrossRef]

Simunic, Dan A., and Michael T. Stein. 1990. Audit risk in a client portfolio context. Contemporary Accounting Research 6: 329-43. [CrossRef]

Smith, B., and Eric Morse. 2005. Entrepreneurial Competencies: Literature Review and Best Practices. Small Business Policy Branch. Ottawa: Industry.

Spencer, Lyle M., and Signe M. Spencer. 1993. Competence at Work: Models for Superior Performance. New York: Wiley.

Stevens, Gregory W. 2013. A Critical Review of the Science and Practice of Competency Modeling. Human Resource Development Review 12: 86-107. [CrossRef]

Straka, Gerald. 2004. Measurement and evaluation of competence. In The Foundations of Evaluation and Impact Research. Third Report on Vocational Training Research in Europe: Background Report. Edited by Pascaline Descy and Manfred Tessaring. Luxembourg: Office for Official Publications of the European Communities.

Taborsky, Barbara, and Rui F. Oliveira. 2012. Social competence: An evolutionary approach. Trends in Ecology E Evolution 27: 679-88. [CrossRef]

Vainieri, M., Francesca Ferrè, Giorgio Giacomelli, and Sabina Nuti. 2019. Explaining performance in health care: How and when top management competencies make the difference. Health Care Manage Review 44: 306-17. [CrossRef] [PubMed]

Winterton, Jonathan. 2019. Competence Across Europe: Highest Common Factor or Lowest Common Denominator? Journal of European Industrial Training 33: 681-700. [CrossRef]

$\mathrm{Wu}$, Chih-Wen, Wei-Wen Chen, and Chun-Hui Jen. 2020. Emotional Intelligence and Cognitive Flexibility in the Relationship Between Parenting and Subjective Well-Being. Journal of Adult Development 2: 106-15. [CrossRef]

Wysokińska-Senkus, Aneta, and Justyna Górna. 2021. Towards sustainable development: Risk managemet for organizational security. Entrepreneurship and Sustainability Issues 8: 527-44. [CrossRef] 